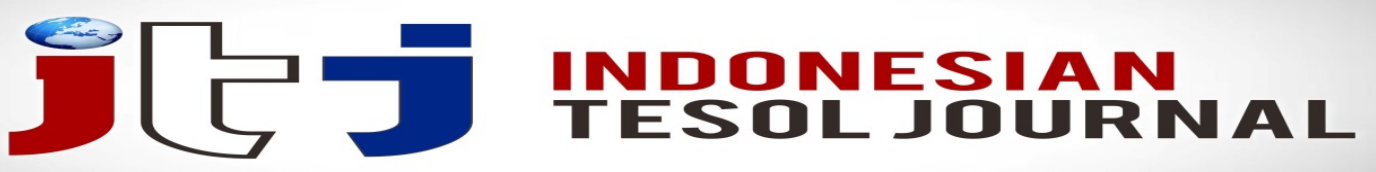

e-ISSN: 2622-5441(Online) Journal homepage: https://ejournal.iainpalopo.ac.id/index.php/ITJ/index

\title{
A Historical Account of Linguistic Imperialism and Educational Policy in Tunisia: From the independence to the 'Jasmine Revolution'
}

\author{
Leila Najeh Bel'Kiry \\ Sfax University, Tunisia
}

\begin{abstract}
This article is about foreign languages hegemony in Tunisia. It describes the linguistic situation at the macro and micro levels, the Tunisian and the international linguistic communities, the status of English and French languages throughout the world, and their effects on the Tunisian educational policy. The prevalence of French in Tunisia as the language of science and technology between 1956 and 1987, the way the value of English is promoted in the Tunisian educational system between 1987 and 2011 though Tunisia is a French colonized country, and the tendency to linguistic isolationism since 2011, prove the intrinsic link between language and politics. Political changes at international and local levels shape the local linguistic communities.
\end{abstract}

Keywords: Educational policy in Tunisia; foreign language teachin; languages Hegemon; linguistic imperialism.

\section{INTRODUCTION}

Linguistic imperialism is a political concept that made its way into applied linguistics first in the work of the English scholar, Phillipson (1992). It describes the hegemony of English as a global language and as a form of the AngloAmerican control over the world. It is a new form of American domination over friends and enemies alike. Armstrong (cited in Harvey, 2005, p. 80) captures this hegemony in the following depiction:

The plan is for the United States to rule the world. The overt theme is unilateralism, but it is ultimately a story of domination. It calls for the United States to maintain its military superiority and prevent new rivals from rising up to challenge it on the world stage. It calls for dominion over friends and enemies alike. It says not that the United States must be more powerful, or most powerful, but that it must be absolutely powerful.

The historical record shows that English imperialism has not developed overnight. It is the outcome of a piecemeal process that has started in the United States since World War II. Six decades ago, around hundred million people spoke English; most of them were living in the UK. Nowadays, more than 1.8 billion people around the world speak English (Crystal, 2006 pp. 420-439).

Then, what is the relation between the drastic changes that World War II brought to languages and imperialism as a political concept that describes any 
system of domination and subordination organized with an imperial center and a periphery (Said, 1994. p. 9)? Is this relation by sheer coincidence or is it due to the emergence of the USA as an international power, resulting in a quick 'boom' of English that has escalated from a national language to an international language and finally to a global language? Halliday (2006) interpreted the relation between the hegemony of English language worldwide and economic and technological prosperity as follows:

English has become a world language in both senses of the term, international and global: international, as a medium of literary and other forms of cultural life in (mainly) countries of the former British Empire; global, as the cogenitor of the new technological age, the age of information. So those who are able to exploit it, whether to sell goods or ideas, wield a very considerable power. [...]. Global English has expanded - has become "global" - by taking over, or being taken over by, the new information technology, which means everything from email and the internet to mass media advertising, news reporting, and all the other forms of political and commercial propaganda. (pp. 362-363)

There is a strong tie between language and imperialism. This relationship is intriguing because imperialism is an umbrella term that covers many forms of political, economic, technological, military and linguistic domination. According to Stephen (2002, p. 10), imperialism is a whole ideological process that concerns itself more with conquest over expansion than with political side. Imperialism has to do with the power that one state has over another. Stephen even distinguished between two forms of imperialism: Formal and informal imperialism. Formal imperialism is the best known and the oldest form. It is related to the physical and economic domination or control of a group of people over another. As for informal imperialism, including linguistic imperialism, it is the indirect form of control. Nonetheless, it is still a powerful form of dominance.

The persistent growth of English and its shift (from local language to international language) may be politically explained in the sense that everything is political, even language. In Duverger's words, "Anglo-American is the most powerful language militarily and economically speaking. As such, we have to acquire this language" $(2007$, p. 8). Graddol $(2000$, p. 8) lists a set of major domains (science, technology and business) of English (see Table 1). The set shows the hegemony of English as a global language.

Table 1. Major international domains of English

\begin{tabular}{cl}
\hline No. & \multicolumn{1}{c}{ Domains } \\
\hline 1. & Working language of international organizations and conferences \\
\hline 2. & Scientific publication \\
3. & International banking, economic affairs and trade \\
4. & Advertising for global brands \\
5. & Audio-visual cultural products (e.g., film, TV, popular music) \\
6. & International tourism \\
7. & Tertiary education \\
8. & International safety (e.g., airspeak, seaspeak) \\
9. & International law \\
\hline
\end{tabular}


10. As 'relay language' in interpretation and translation

11. Technology transfer

12. Internet communication

\section{ENGLISH IMPERIALISM AND FOREIGN LANGUAGES TEACHING RESEARCHES: THE SAME HISTORICAL TRAJECTORY}

With the emergence of the United States as a world power after World War II, the English language established itself as a global language for reasons related to economic prosperity, cultural colonialism and military powers (Crystal, 2006; Gradol, 2000). Fishman (1999) explained the reason behind the preeminence of English saying that "historically, languages have risen and fallen with the military, economic, cultural or religious powers that supported them" ( $p$. 27). Relying on the linguistic orthodoxy that all languages are equal, Pennycook (2013) argues that the growth of English as a global language has nothing to do with the structure of the language, or any inherent qualities; however, it has everything to do with politics. In the same vein, Gradol $(2000$, p. 5) states that "languages are unequal in political or social status."

Pennycook's claim aligns with the synoptic overview about the developments in EFL methods and approach presented in this thesis. It shows that innovation in FLT began in the late $19^{\text {th }}$ century and burgeoned in the $20^{\text {th }}$ century (Howatt \& Smith, 2014). It is obvious, then, that this era is the hybrid vigour of the English empire and later the American power, which has come to govern the world in all respects. Is it by coincidence that FLT as a sub discipline in applied linguistics, the emergence of the United States as an international power and English imperialism have the same historical trajectory? For Phillipson (2012), it is not a coincidence because the global teaching of English was an act of linguistic imperialism; therefore, FLT researches were promoted then.

In the same direction, some scholars (Bloomfield, 1993; Crystal, 2006; Graddol, 2000; Kachru, 1985; Pennycook, 2013; Phillipson, 2012) found a link between the outbreak of the two World Wars and the shifts in the international linguistic community. World War II brought an abrupt end to linguistic isolationism. There was a risk within the armed forces that large numbers of American soldiers would soon be scattered throughout a large proportion of the globe and there was a fear that if they did not use their English language, they would lose their identity (Moulton 1993, p. 84).

Correspondingly, Great Britain, the traditional strategic ally of the United States, joined the American project towards its new imperialism: The linguistic imperialism. British politicians predicted that the next wars would be of words; those who possess the language will dominate the world. Therefore, they started promoting their language overseas. Churchill realized that military control over the world is costly for them. Upon receiving an honorary degree, Churchill claimed in his speech, delivered on 6 September, 1943, at Harvard University, that the power to control language offers far better prizes than taking away people's provinces or lands or grinding them down in exploitation and that the empires of 
the future are the empires of the mind. It is also reported in the British cabinet report of 1956 that within a generation, English could be a world language - that is to say, a universal language in those countries in which it was not already the native or primary tongue.

To safeguard this linguistic hegemony, the United States of America and Great Britain have invested in English learning at home and overseas since the 1940's. At home, since World War II, linguists from the USA were called upon to develop scientific methods of training personnel in foreign languages for military purposes. Lado (1957) and Fries and Lado (1958) invented a new teaching method, known as the army method, devoted to defensive and military purposes, specifically to teaching soldiers the language of the invaded countries (Quivy \& Tardieu 2002, p. 166) as a first step towards the propagation of English. This is because foreign language learners have a tendency to transfer the forms and meanings of their native language and culture to the foreign language and culture - both productively when attempting to speak the language and act in the culture, and receptively when trying to grasp and comprehend the language and culture as practised by natives (Lado 1957, p. 2).

As a positive response to the governmental encouragement to FLT researches, the competition reached its peak among scholars to invent a teaching method that would meet all needs. Over the course of five decades (between 1950 and 2000), a set of teaching methods were introduced. Davies $(2007$, p. 66) stated that the history of foreign language learning is a history of method. Like fashion in dress/clothes, approaches to language teaching emerge and disappear, and if one looks far enough, it recycles itself at intervals. It is clear, then, that the organizations founded overseas, such as the British Council in 1934 and the Euromonitor International in 1972, were part of the international policy to promote and preserve the English language all over the world, especially in developing and underdeveloped countries.

Apart from such organizations, many incentives have been given to ensure the existence of English as an important compound in the international linguistic community. Such incentives are in the form of grants provided to local organizations organizing programs related to English language teaching and learning. These grants would support local travel, speaker honorarium, and materials (Source: the website of American Embassy in Tunisia). Equally, to encourage people all over the world to speak English, the British Council offers new programs, like 'English Access Micro scholarship Program (Access)', 'ETeacher', 'English Language Specialist', 'English Language Fellow', 'Exchange Programs' as well as materials for English language learning and teaching such as online resources for students and teachers.

\section{THE LINGUISTIC SITUATION AT THE MICRO LEVEL: LINGUISTIC DIVERSITY IN THE TUNISIAN LINGUISTIC COMMUNITY}

The linguistic situation in Tunisia is complex. Tunisia is at the same time homogeneous and heterogeneous in terms of language. Bahloul (2001) describes this linguistic community as an "extremely colorful mosaic that is made up of a significant number of language varieties" (p.4). Many factors, namely 
geographical and strategic position, shape the linguistic communities. However, linguistic attitudes remain constant. This depends on many other variables, mainly historical changes (Crystal, 2006). Though it is located at the crossroads between Africa and Europe, Tunisia is the most homogeneous community in North Africa at the linguistic level. Tunisia uses standard Arabic as the official language in addition to Tunisian Arabic dialect. The latter is considered as a low variety of Arabic. It comprises at least six major dialects geographically defined: the main dialect varieties of Tunisian Arabic are Northwestern Tunisian, southwestern Tunisian, Tunis dialect, Sahil dialect, Sfax dialect and southeastern Tunisian. These varieties do not differ structurally, but they tend to be different phonologically and lexically (Abdesslem 1987, p. 152).

Arabic, the official language, was used centuries ago in the Arabian Peninsula. Though other languages (Berber, Punic, etc) preceded the Arabic language in Tunisia, Arabic has been used as the first official language in the history of Tunisia. Article 1 in the Tunisian Constitution states that Arabic is the official language in Tunisia. However, throughout its history, Tunisia has been open to both West and East. The history of Tunisia shows that many languages, like Berber, Punic, Latin, Arabic and French, have succeeded each other (Abdesslem 1987, p. 171). The two world wars in the last century were the most influential historical events that have shaped the modern linguistic community in Tunisia as a colonized country. Multilingualism, the hegemony of foreign languages, mainly French and English, is the most obvious legacy of the colonial period.

This hegemony was sharpened by the American control all over the world in all respects (economic, technological, scientific, etc) and Tunisians have a mania for learning foreign languages, mainly French and English. The Tunisian government thinks that the English language is much more important than the Arabic language. This positive attitude towards English proves the success of the USA in "globalizing America" at the economic, scientific, cultural, and linguistic levels (Brewer \& Boyd, 2000). This explains why the value of English has witnessed a persistent attention to the point that it has become a second language (The Development of Education: National Report, 2004/2008), while French has lost its prominence in Tunisia as in other French colonies since its use seems to have decreased (Bouhris 1982, p. 307).

\section{Teaching foreign languages in Tunisian policy}

Habib Bourguiba, the first president of Tunisia, gave the impetus of a modern educational policy which has changed radically and continuously since independence. Like other ruling elites of many francophone states who qualified in France (Bouhris 1982, p. 305), Bourguiba saw that French was essential to modernize the Tunisian society. He stated his view explicitly in a speech delivered in Montréal, on 11 May, 1968:

And it is through the French language that we have been able to forge a new representation of our national will, that we have been able to communicate it, propagate it, make it heard, make it understood. In the French-speaking world, of course, but even beyond the borders of this linguistic universe, it is through the use 


\begin{abstract}
of the French language that we have been able to make Tunisia's voice heard in the concert of nations. Thus, we were able to draw from all over the world, on the American continent and up to the United Nations, not only the comfort but the support that we needed to lead our struggle for the recognition of our identity to victory, and our national dignity, in short for independence (...) This is why, once independence has been acquired, we have maintained in our education system and from the primary grades, the teaching of French. This is why the use of French has retained its place in Tunisia. (p. 4-2)
\end{abstract}

The first embodiment of Bourguiba's project was the foundation of the Bourguiba Institute of Modern Languages in 1962 to specialize in teaching foreign languages, mainly English and French. The intention of establishing Bourguiba School dated back to 1958 when night lessons were organized by the American Cultural Center. After two years, the first decree was made to Tunisify such lessons (Decree $\mathrm{n}^{\circ}$ 64-51,13; February 1964). Then, a second decree in January 1976 attached Bourguiba School Institute to the Tunisian University. Through this decree, two functions were assigned to the Bourguiba School: (i) teaching Arabic language to foreigners and foreign languages to Tunisians; (ii) Training translators. In 1978, Bourguiba School became a university institution of language, delivering combined certifications in languages and translation (Source: Institut Bourguiba des Langues Vivantes (IBLV) Web site).

The two following paragraphs tackle the Tunisian official attitude towards FLT at three different historical landmarks: (i) the first phase extending from independence to 1987 when Ben Aly, the second president of Tunisia came to power, (ii) the second phase started in 1987 and ended in 2011 when the regime of Ben Aly was toppled, and (iii) the last one started with the Jasmine revolution. Indeed, the two first periods were characterized by common concerns with overall reforms and positive attitudes towards FLT, while new policy and attitudes could be anticipated in the last phase, which brought into power the opponents of both Bourguiba and Ben Aly.

\title{
Foreign language teaching: A priority in Tunisian educational reforms
}

The French language was given educational and linguistic privileges in Tunisia for a number reasons. According to Aouina (2013, p. 23), the French language gained this status because of its prevalence as the language of science and technology, immigration to France, and historical and cultural considerations. Most elites, especially Francophones, believed that French is the doorway to prosperity at the economic, social, scientific levels. This belief was incorporated into orthodox educational reforms because promoting FLT in the educational system has been a priority in most conducted reforms since independence.

The first phase: From the independence (1956) until (1987)

To serve and preserve the French language many institutions (Lycée Gustave Flaubert, College Charles-Nicolle, Ecole Paul-Verlaine, Ecole JeanGiono, Ecole George-Sand, etc) were founded since the colonial period (Aouina, 2013 p. 24). A policy that launched a new tendency towards bilingualism and put a strain on the relationship between Francophone leaders and nationalists who feared that the French language would erode the Arabic language while Islamic 
identity was taking shape. Bouhdiba (2011) depicted this trend in the following way:

This orientation of education towards bilingualism is done despite nationalist pressure from unilingual Arabic speakers, trained at Zitouna University (AitChaalal and Legrand, 1997: 94). In fact, while the fledgling Tunisian government is not openly hostile to Arabization, the real priority in education is the democratization of education and the training of the country's future cadres. This last point is all the more urgent in that French executives began to leave the country in the mid-1950s. (p. 3)

The contention reached its peak when the Zeitounians decreased in number and the Koranic schools ( Elko'tab) were closed. Meanwhile, the private French schools were supervised by the state, along with the Arabization of only first and second year elementary schools; the rest of the school curriculum was now a balance between the two languages: 70 hours monthly for Arabic and 60 hours monthly for French from $3^{\text {rd }}$ year (Bouhdiba 2011, p. 4). In his speech in October 1968, Bourguiba justified these regulations as follows:

\begin{abstract}
Using French does not undermine our sovereignty or our loyalty to the Arabic language, but gives us a wide opening to the modern world. If we have chosen French as the lingua franca, it is to better integrate ours into the current of modern civilization and catch up more quickly ... And it is too little, finally, when we speak of Tunisia, to emphasize its bilingualism: it is rather a matter of biculturalism.
\end{abstract}

The regulations introduced by Bourguiba compelled Muhammad Lamine Eshebby, the Secretary of State for National Education, to resign in 1958 and Mahmud Elmessedy succeeded him, apolitical leader from among those Tunisian elites trained in France. Once at the head of the Ministry of Education (19581968), Elmessedy started his reform plan: modernizing Tunisia through cultural openness and positive attitudes towards foreign languages.

Elmessedy's project was an embodiment of the priority given to FLT in the Tunisian educational system. He tried to break away from the traditional education which was characterized by linguistic isolationism only for Arabic, the national language which had been adopted in the official teaching programs. However, Arabic was not, and could not be, used as the language of science and technology and total Arabization, or even significantly greater Arabization, was not attainable (Stevens 1974, pp. 328-329). For this matter, Elmessedy started a new policy of anti-isolationism to put an end to the negative attitude towards foreign languages which had prevented prosperity.

Following Elmessedy's regulations, French was adopted officially as the second language used in three major settings: schools, universities, and formal settings (this is the major legacy of Elmessedy's regulations). Another important gain of such regulations was the appearance of new elites that replaced the French specialists and top administrators working in Tunisia (Abdesslem 1987, p. 153). These elites had a positive impact on Tunisian autonomy.

Elmessedy left his office in October 1968. His successor, Ahmed Ben Salih, carried on and developed Elmessedy's project. He suggested a major 
project to boost foreign languages and local language equally. Bouttemont (2002) wrote:

From 1970, a reform aimed at the Arabization of education was adopted. The primacy is then given to the Arabic language which becomes the lingua franca of all disciplines. French is becoming a supplementary language, a language of information and communication allowing access to scientific and technical culture. At the same time, the Arabization of technical and scientific education has been launched and constitutes an important axis of educational policy. It nevertheless encounters serious difficulties. (p. 2)

This policy did not resist the new linguistic imperialism and the hegemony of English. Muhammad Charfi launched a new reform and called for preparing students better to assume the duties of citizenship in a world that every day becomes more cosmopolitan (Charfi \& Redissi 2010, p. 149). Charfi's aim was to integrate Tunisia into the international linguistic community dominated by the English language, without renouncing the French language for historical and strategic reasons.

Thus, after almost one century of domination, the value of the French language in the Tunisian community is receding and superseded by English though French is still a second language in Tunisia. The possibility of replacing French by English is a potential, seeing the growing international dependence of the world on English and the continual receding of French (Battenburg, 1997).

Because of this new situation, the controversy was not over the dominance of French and Arabic languages, like in the post war period. Rather, the rivalry is between the French and English languages. Some parliamentarians called for the adoption of English as a second language for even the French have realized that their language is no longer the international language of diplomacy, treaties, and nobility that it once was (Gordon \& Meunier 2001, p. 34). The following table shows the fluctuation of the value of French in the Tunisian educational system.

Table 2. The French Language in Tunisia: (Adapted from Kammoun 2006, p. 10)

\begin{tabular}{ccc}
\hline No. & School year & $\begin{array}{c}\text { Year of first } \\
\text { introduction of French }\end{array}$ \\
\hline 1. & $1958-1968$ elementary school & Year 3 \\
\hline 2. & $1968-1971$ elementary school & Year 3 \\
3. & $1971-1976$ elementary school & Year 1 \\
4. & $1976-1977$ elementary school & Year 2 \\
5. & $1977-1986$ elementary school & Year 4 \\
\hline
\end{tabular}

Second phase: From 1987 to 2011

Like Bourguiba, Ben Aly, the second president of Tunisia, had positive attitudes towards FLT. Promoting FLT had a stake in most regulations taken during Ben Aly's rule. Pupils of $8^{\text {th }}$ Form of prep. school started learning English from the academic year 1996/1997. In 2000, the value of English was promoted by another regulation of teaching English in the $7^{\text {th }}$ Form of prep. school (Derbel, 2001). Such regulations were followed by a reform launched in 2002: La Nouvelle Reforme du Systeme Educatif Tunisien Programme pour la Mise en Oeuvre du 
Projet 'Ecole de Demain' "2002 - 2007” that promoted FLT in general and English in particular:

Given the importance of foreign languages and their role in opening up to modernity and universal civilization, the Ministry has consolidated the teaching of foreign languages by adopting the following measures: - The establishment of teaching in 1996/1997 of English from the $8^{\text {th }}$ year of basic education instead of the $1^{\text {st }}$ year of secondary education, and thus, compulsory education of this language will span 6 years instead of 4 .

Nonetheless, the sole difference between the attitude of Ben Aly and that of Bourguiba is that French has lost its supremacy for the stake of English (Kammoun, 2006) as shown in Table 3:

Table 3. English and French Languages in IBLV (Source: Institut Bourguiba des Langues Vivantes (IBLV) Web site)

\begin{tabular}{cccc}
\hline \multirow{2}{*}{ No. } & Year & \multicolumn{2}{c}{ Number of students } \\
\cline { 3 - 4 } & & French & English \\
\hline 1. & 2006 & 1454 & 3354 \\
\hline 2. & 2007 & 1543 & 2830 \\
\hline 3. & 2008 & 1644 & 3163 \\
\hline 4. & 2009 & 1754 & 3084 \\
\hline
\end{tabular}

Additionally, statistics (Aouina, 2013; Daoud, 2001) show that English was valued as a foreign language that experienced a sudden rise in attention following the 1990's. The era was characterized by a radical change in the international political scene. This affected Tunisian international relations (Abdesslem 1987, p. 159). The 1990's witnessed the decline of Soviet Union, the first competitor of the United States of America. Such a decline paved the way for Americans to spread their hegemony over the world. It is not a coincidence that by the end of the decade (in 1997), the level of English was improving thanks to governmental regulations that included: (i) starting English language education at earlier stages of primary education; it has been taught as a compulsory subject from grade 5 in elementary school since 2005 (Republic of Tunisia, Ministry of Education and Training: The development of education, National Report, $2004 / 2008$, p. 30), and (ii) implementing many teaching methods to meet the international norms of FLT as introduced in the language teaching standards by the American Council on the Teaching of Foreign Languages (ACTFL) and the (TESOL) Teachers of English to Speakers of Other languages (Republic of Tunisia, Ministry of Education and Training: The development of education: National Report, 2004/2008, p. 29).

By contrast, the value of French in the Tunisian policy reached rock bottom in the last reform in favor of English. In this reform, it is stated that:

...the French schedule will be gradually reduced in the first cycle of basic education, English learning will begin earlier and the schedule allocated to it will be increased. In this sense, it was decided to devote - within the framework of club activities - three compulsory hours per week to this language in the $5^{\text {th }}$ and $6^{\text {th }}$ years of basic education. (2002, p. 70) 
The new status of French in the Tunisian policy was influenced by the international attitudes towards French and English as two influential languages. The French politicians themselves realized that English is dominating French for economic and technological considerations. In his speech delivered in 1997, the French Education Minister, Claude Alègre, affirmed that "English had become a commodity, similar in kind to computers or the internet [...] The French have got to stop thinking of English as a foreign language" (in Wright 2004, p. 125). This situation worsened.

Does the so-called Jasmine Revolution forecast the end of multilingualism in Tunisia?

The Tunisian Revolution and Independence are two important events that have great impact on the political, social, economic background and particularly on the linguistic community. My judgment is based on the fact that the return of Tunisian politicians from France after the independence was the direct factor for promoting the French language in Tunisia. However, the return of political expatriates, most of them Islamists and nationalists, raised the question of identity and language. Such questions have great influence on the status of FLT in Tunisia.

Despite the fact that most Islamists and nationalists had been expatriates in the UK, they did not show enthusiasm towards English. Controversially, syndromes of new linguistic isolationism emerged like the Koranic schools which could remove foreign languages in favor of Arabic as a local language. In addition, once in power after the election of 2011, the Islamist leader, Rachid Ghannouchi, criticized the linguistic situation in Tunisia when he stated that "we have become Franco-Arabic, it is linguistic pollution... He who is not proud of his language is not proud of his homeland." This negative attitude was sharpened by the obscure educational policy and the absence of reforms prioritizing FLT.

As a response to this new policy characterized by a negative attitude towards FLT, and for fear that English would lose its status in the Tunisian linguistic community, the American government has provided many incentives to ensure the existence of English as an important component in the Tunisian linguistic community. These incentives are in the form of grants, and aids have been apparently offered to sustain Tunisian efforts to attract greater foreign investment through aid, trade delegations, and negotiations under the USA and for security concerns (Arieff \& Humud 2015, p. 14). However, this encouragement also seeks to preserve the English hegemony in the Tunisian linguistic community.

In the same spirit, many conferences and events were organized by the British Council, British Embassy, and Tunisian TESOL to promote English in the Tunisian linguistic community. 'English Language Week,' in May 2014, was an event led by the British Council and the British Embassy in Tunis, in partnership with UTICA (l'UnionTunisienne de l'Industrie du Commerce et de l'Artisanat) and TBCC (Tunisian British Chamber of Commerce). This event discussed the importance of languages, and English in particular, for employability. 
- 'Tunisia speaks English' another event was organized in November 2015 and aimed at convening and allowing delegates to propose a series of recommendations that could be taken forward by stakeholders in the context of the current reform process being undertaken by the Ministry of Education, the Ministry of Vocational Training and Employment, the Ministry of Higher Education and Scientific Research, and other stakeholders to help improve the levels of English language proficiency of students finishing school, vocational training and university.

- English Language Month 2015: 'English opens doors' is a national campaign organized by the British Council and British Embassy Tunis in November. Its aim was to promote the importance of languages and in particular better levels of English to improve the employability of young Tunisians.

- Digital English Tunisia 2015: Teaching and Learning English with today's technology. The event attracted about 500 educators, and brought together English language practitioners working in all educational sectors across Tunisia and the UK. It aimed at granting access to current innovations in teaching and learning English with today's technologies to help improve the quality of language teaching and learning in Tunisia.

\section{CONCLUSION}

Though Article 1 of the Tunisian Constitution decrees Arabic as the official language, the language profile in Tunisia remains diversified mainly for historical considerations. In Tunisia, the 'footprints' of the French colonists were not only marked at political and economic levels.

In addition, the legacy of the French colonization shaped the Tunisian linguistic community. For decades, French language has been 'a fashion' in Tunisia and a criterion which has helped a person to attain higher social status in the Tunisian society, rich and high class people used French language in their everyday life.

However, the rise of the United States of America as a global power has a great impact on the international linguistic community. The value of English language in Tunisia reached its peak, and was promoted by the Tunisian educational policy-makers who support the incorporation of FLT. This local policy is a part of an international policy conducted by the USA to control the world through linguistic hegemony.

\section{REFERENCES}

Abdesslem, H. (1987). An analysis of foreign language lesson discourse :With special reference to the teaching of English in Tunisian secondary schools (Doctoral thesis, University of Sheffield,England). Retrieved from http://etheses.whiterose.ac.uk/1813/1/DX190328.pdf 
Aouina, H. (2013). Globalization and language policy in Tunisia: Shifts in domains of use and linguistic attitudes (Doctoral dissertation, University of the West of England).

Arieff, A., \& Humud, C. (2014). Political Transition in Tunisia. Current Politics and Economics of Africa, 7 (4), 497-521. https://fas.org/sgp/crs/row/RS21666.pdf

Armstrong, D. (2002, October ). Dick Cheney’s Song of America: Drafting a plan for global dominance. Harper's Magazine Foundation. Retrieved from https://harpers.org/archive/2002/10/dick-cheneys-song-of-america/

Bahloul, M. (2001). English in Carthage; or, the "Tenth Crusade". http://www.postcolonialweb.org/poldiscourse/casablanca/bahloul2.html/, accessed 20 March 2017.

Battenburg, J. (1997). English versus French: Language rivalry in Tunisia. World Englishes, 16 (2), 281-290.

Bloomfield, L. (1993). About foreign language Teaching. Landmarks of American Language and Linguistics, 1,40-49.

Bouhdiba, S. (2011). L'arabe et le français dans le système éducatif Tunisien: Approche démographique et essai prospectif. Québec:

Observatoire démographique et statistique de l'espace francophone, Université Laval. Retrieved from

https://www.odsef.fss.ulaval.ca/sites/odsef.fss.ulaval.ca/files/rapport_bouh diba.pdf

Bouhris, R. (1982). Language policies and language attitudes: Le Monde de la Francophonie. In Rayan, E.B \& Giles (Eds.), Attitudes towards language variation social and applied context ( pp 306-322). London: Edward Arnold.

Bouttemont,C. D. (2002). Le système éducatif Tunisien. Revue internationale d'éducation de Sèvres, (29), 129-136.

Brewer, T. L., \& Boyd, G. (2000). Globalizing America: The USA in world integration. Edward Elgar Publishing. New horizons in international business

Crystal, D. (2006). English as a global language (2 ${ }^{\text {nd }}$ ed.). Cambridge: Cambridge University Press.

Daoud, M. (2001). The language situation in Tunisia. Current Issues in Language Planning, 2 (1), 1-52. Retrieved, from file://C:/Users/dell/Downloads/daoud2001.pdf.

Davies, A. (2007). Introduction to applied linguistics: From practice to theory. Edinburgh: Edinburgh University Press. 
Derbel, F. (2001). EFL teacher preparation, teacher conceptual frame and the task of implementing pedagogical change: Direction for the future teacher education and development in Tunisia.(Doctoral thesis, University of London Institute of Education, London). Retrieved from http://discovery.ucl.ac.uk/10020366/1/536670vol1.pdf

Duverger, J. (2007). École élémentaire et enseignement des langues. Tréma, 28, 17-22. Retrieved from https://journals.openedition.org/trema/259

Fishman, D. (1999). The case for pragmatic psychology. New York: NewYork Univeristy Press.

Fries, C. C., \& Lado, R. (1958). English pattern practices: Establishing the Patterns as Habits (An Intensive Course in English). Michigan: Michigan University, English Language Institute.

Gordon, P. H., \& Meunier, S. (2001). Globalization and French cultural identity. French Politics, Culture \& Society, 19 (1), 22-41.

Graddol, D. (2000). The future of English: A guide to forecasting the popularity of the English language in the $21^{\text {st }}$ century ( $2^{\text {nd }}$ Ed.). London: The British Council.

Halliday, A. K. (2006). Written language, standard language, global language. In Kachru, B., Yamuna Kachru and Cecil B. Nelson eds. The Handbook of World Englishes (pp. 349-365). Malden, MA and Oxford: Blackwell.

Harvey, David (2005). The new imperialism. Oxford: Oxford University Press.

Howatt, R. \& Smith, R. (2014). The history of teaching English as a foreign language, from a British and European perspective. Language and history, 57 (1), 75-95.

Kachru, B. (1985). Standards, codification and sociolinguistics. In Quirk, R. and Widdowson, H. (eds) English in the World: Teaching and Learning the Language and Literatures (pp. 11-30).

Kammoun, R. (2006). Diversité linguistique en Tunisie : Le français a-t-il perdu de sa suprématie? FIPLV WORLD CONGRESS 2006 Goteborg Sweden, June 15-17, 2006.

Lado, R. (1957) Linguistics across cultures: Applied linguistics for language teachers. University of Michigan Press.

Moulton, W. (1993). Linguistics and language teaching in the United States 1940 - 1960. Landmarks of American Language and Linguistics, 1, 170-189.

Pennycook, A. (2013). The cultural politics of English as an International Language. London: Routledge.

Phillipson, R. (1992). Linguistic imperialism. Oxford: Oxford University Press. 
Phillipson, R. (October 2012). English: from British empire to corporate empire. ReasearchGate, Sociolinguistic Studies. doi:10.1558/sols.v5i3.441

Quivy, M., \& Tardieu, C. (2002). Glossaire de didactique de l'anglais. Ellipses.

Said, E. (1994). Culture and imperialism. New York: Vintage Publishers.

Stephen, H. (2002). Empire: A very short introduction. Oxford: Oxford UP, Print.

Stevens, P. S. (1974). French and Arabic bilingualism in North Africa with special reference to Tunisia: A study of language attitudes and language use patterns. Unpublished PhD Dissertation.

Wright, S. (2004). Language Policy and Language Planning: From Nationalism to Globalisation. New York, NY: Palgrave Macmillan. 